\title{
Manajemen Sumberdaya Keluarga Peserta Program Pemberdayaan Masyarakat Di Kabupaten Bogor
}

\section{Family Resource Management of Participants of Community Empowerment Program in Bogor Regency}

\author{
Tin Herawati ${ }^{1}$, Basita Ginting S ${ }^{1}$, Pang S. Asngari ${ }^{2}$, Djoko Susanto ${ }^{2}$, Herien Puspitawati ${ }^{3}$ \\ ${ }^{1}$ Mahasiswa Mayor Ilmu Penyuluhan Pembangunan 2007, Sekolah Pascasarjana IPB \\ Instansi tempat bekerja : Departemen Ilmu Keluarga dan Konsumen, Fakultas Ekologi Manusia, IPB \\ ${ }^{2}$ Staf Pengajar pada Mayor Ilmu Penyuluhan Pembangunan, Sekolah Pascasarjana IPB \\ ${ }^{3}$ Staf Pengajar Mayor Ilmu Keluarga dan Perkembangan Anak, sekolah Pascasarjana IPB
}

\begin{abstract}
Nowdays it is difficult for many families to achieve an ideal life, this situation cause, formulation managing human resource which has a good quality is not optimal. The important thing must be carried out to make the families maintain their life is to manage the limited resource by the family resource management. This research analyzed the family resource management of participant in empowerment program and the factors that influenced them. The research design was crossectional study using survey method to collect data from 300 respondents. The result showed that highest percentage of respondent carried out the family resource management categorized as bad. There was a significant difference between the family resource management at Dramaga District and Leuwisadeng District or Pamijahan District $(\alpha<0.05)$. The factors which significantly influence the family resource management are income per capita, the family communication quality, the occupation status of spouse and the participation in extension program.
\end{abstract}

Keywords: family resource management, community empowerment, income per capita, extension program, communication quality

\begin{abstract}
Abstrak
Pada saat ini banyak keluarga yang mengalami kesulitan dalam menjalani kehidupan yang layak, sehingga pembentukan sumberdaya manusia berkualitas menjadi tidak optimal. Hal penting yang harus dilakukan agar keluarga dapat bertahan menjalani kehidupannya, adalah mengatur sumberdaya yang terbatas melalui manajemen sumberdaya keluarga. Penelitian ini mengkaji manajemen sumberdaya keluarga peserta program pemberdayaan dan faktor-faktor yang mempengaruhinya. Desain penelitian crossectional study, dengan teknik pengumpulan data menggunakan metode survei pada 300 responden. Hasil menunjukkan persentase tertinggi responden melakukan manajemen sumberdaya keluarga tergolong kurang baik. Terdapat perbedaan yang signifikan manajemen sumberdaya keluarga di Kecamatan Dramaga dengan Kecamatan Leuwisadeng dan Pamijahan $(\alpha<0.05)$. Faktor yang berpengaruh nyata terhadap praktek manajemen sumberdaya keluarga adalah pendapatan perkapita, kualitas komunikasi keluarga, status bekerja suami isteri dan partisipasi dalam kegiatan penyuluhan.
\end{abstract}

Kata Kunci : Manajemen Sumberdaya Keluarga, Pemberdayaan Masyarakat, Pendapatan Perkapita, Program Penyuluhan, Kualitas komunikasi

\section{Pendahuluan}

Pada saat ini banyak keluarga yang mengalami kesulitan dalam menjalani kehidupan yang layak akibat krisis dan kenaikan harga bahan bakar, sehingga pembentukan sumberdaya manusia berkualitas menjadi tidak optimal. Program pemberdayaan merupakan salah satu bentuk intervensi yang dilakukan oleh

\footnotetext{
${ }^{1}$ Korespondensi penulis, email: gmsk_29@yahoo.com.
}

berbagai pihak untuk menanggulangi permasalahan yang dihadapi keluarga. Menurut Sumodiningrat (1999), inti pemberdayaan adalah pengembangan, memperkuat potensi atau daya, dan terciptanya kemandirian. Chamber (1995) menyatakan bahwa pemberdayaan masyarakat merupakan paradigma pembangunan masyarakat yang bersifat people centred, participatory, empowering, dan sustainable. Dalam pelaksanaannya program pemberdayaan tidak cukup hanya memberi bantuan materi saja. Menurut Chamber (1995), 
salah satu upaya yang penting dalam strategi pemberdayaan adalah proses pendidikan, baik yang bersifat formal maupun nonformal. Berkaitan dengan pendapat tersebut maka penyuluhan sebagai suatu proses pendidikan nonformal merupakan hal penting dalam strategi pemberdayaan. Aktivitas pemberdayaan tidak terlepas dari fungsi-fungsi penyuluhan (Satria, 2009). Asngari (2001) menyatakan bahwa penyuluhan adalah pendidikan nonformal untuk mengubah perilaku, dan membangunkan orang untuk mengetahui ada peluang baru yang lebih baik untuk kehidupan yang lebih baik.

Selain adanya dukungan dari program pemberdayaan, hal penting yang harus dilakukan agar keluarga dapat bertahan menjalani kehidupannya, adalah mengatur sumberdaya yang terbatas melalui manajemen sumberdaya keluarga. Menurut Deacon \& Firebaugh (1988), manajemen sumberdaya keluarga adalah suatu proses yang dilakukan oleh keluarga dan anggotanya dalam merencanakan dan melaksanakan penggunaan sumberdaya, untuk mencapai tujuan. Aplikasi manajemen sumberdaya keluarga dapat diterapkan dalam manajemen keuangan, manajemen waktu dan pekerjaan, serta strategi koping. Menurut Gross et al. (1980), manajemen sumberdaya keluarga merupakan hal penting bagi tercapainya tujuan keluarga. Fuaida (2007) menyebutkan, bahwa pencapaian tujuan pemberdayaan terkait juga dengan kemampuan keluarga dalam melakukan manajemen sumberdaya keluarga. Mengingat pentingnya manajemen sumberdaya keluarga dalam mencapai tujuan keluarga, maka peneliti melakukan kajian manajemen sumberdaya keluarga, dengan kasus peserta program pemberdayaan di Kabupaten Bogor. Tujuan penelitian adalah menganalisis: (1) karakteristik keluarga, (2) manajemen sumberdaya keluarga, dan (3) faktor-faktor yang mempengaruhi manajemen sumberdaya keluarga.

\section{Kajian Teori}

Sebagai unit terkecil dalam masyarakat, setiap keluarga berusaha mencapai ketahanan keluarga sehingga mampu memenuhi kebutuhan fisik, sosial, mental dan spiritual para anggotanya. Menurut Deacon \& Firebaugh (1988), untuk mencapai tujuan keluarga, terdapat tiga jenis sumberdaya yang harus dikelola, yaitu manusia, materi dan waktu. Gross et al. (1980) menyatakan, sumberdaya keluarga tidak hanya berasal dari dalam keluarga sendiri (internal) tetapi juga berasal dari lingkungan sekitarnya yakni keluarga itu berada (eksternal). Kondisi sumberdaya tersebut dapat menghambat dan mendorong pencapaian tujuan keluarga. Perubahan pada salah satu nsumberdaya akan berpengaruh pada sumberdaya lainnya dan komponen lain dalam sistem keluarga. Menurut Deacon \& Firebaugh (1988), keluarga adalah unik, karena setiap keluarga memiliki ciri yang berbeda satu dengan yang lainnya. Oleh karena itu, cara keluarga mengelola sumberdaya juga akan berbeda-beda, sehingga output yang dihasilkan berbeda-beda. Perbedaan kemampuan keluarga dalam mengelola sumberdaya, akan menghasilkan variasi keluarga dalam menjalani kehidupannya. Guhardja et al. (1992) menyatakan, peranan anggota keluarga akan menentukan bentuk manajemen dalam mengelola sumberdaya. Menurut Gross et al. (1980), beberapa atribut keluarga yang berpengaruh terhadap manajemen sumberdaya keluarga adalah status sosial ekonomi, pola bekerja anggota keluarga, tahapan kehidupan keluarga dan komunikasi. Deacon \& Firebaugh (1988) menyatakan bahwa adanya bantuan sumberdaya dari pihak luar juga mempengaruhi cara mengelola sumberdaya, terutama pada keluarga berpendapatan rendah. Berbagai hasil penelitian menunjukkan bahwa manajemen sumberdaya keluarga dipengaruhi oleh pendidikan kepala keluarga dan pendapatan keluarga (Iskandar, 2007; Celik, 2007). Hasil penelitian Suparto (2007) menunjukkan bahwa pada umumnya praktek manajemen dalam keluarga dilakukan secara ilmiah karena memang tidak disiapkan secara khusus. Itulah sebabnya pelaksanaannya seringkali menjadi kurang optimal sehingga pencapaian tujuan keluarga juga menjadi tidak optimal. Penelitian Fuaida (2007) menyatakan bahwa keluarga yang berhasil mencapai tingkat kemandirian keluarga adalah keluarga yang 
masih aktif menjadi anggota program pemberdayaan dan melakukan manajemen keuangan keluarga dengan baik. Ketidakaktifan keluarga dalam kegiatan pemberdayaan, terutama terjadi pada tahun keempat disebabkan karena keluarga tidak dapat melaksanakan manajemen keuangan keluarga dengan baik. Lubis (2006) menyatakan bahwa kesalahan mengelola sumberdaya merupakan salah satu penyebab keluarga menjadi miskin, dan sebaliknya, pengelolaan sumberdaya yang baik dapat mengangkat keluarga menjadi tidak miskin karena keluarga lebih tahan dalam menjalani kehidupannya di masa krisis. Hasil penelitian Winter dan Puspitawati (1993) menunjukkan bahwa manajemen sumberdaya keluarga terutama manajemen waktu dan pekerjaan merupakan hal penting bagi tercapainya tujuan keluarga.

Manajemen keuangan keluarga adalah pengelolaan atau pengaturan keuangan keluarga untuk memenuhi semua kebutuhan keluarga sehari-hari yang terdiri dari kebutuhan makanan, pendidikan, kesehatan, pakaian, perumahan, dan lain-lain. Manajemen keuangan sangat penting peranannya dalam mewujudkan kesejahteraan keluarga. Untuk itu berbagai upaya untuk meningkatkan kualitas manajemen keuangan keluarga melalui perencanaan keuangan yang baik dan disiplin sangat diperlukan untuk mendukung terwujudnya keluarga yang sejahtera. Budaya perencanaan dalam pengaturan keuangan juga merupakan salah satu bentuk dari sikap hidup hemat yang berwawasan kedepan menuju ketahanan keluarga (Puspitawati, 2006). Menurut Santoso (2007) ada beberapa alasan mengapa keluarga memerlukan manajemen keuangan yaitu: (1) adanya tujuan yang ingin dicapai, (2) tingginya biaya hidup saat ini, (3) naiknya biaya hidup dari tahun ke tahun, dan (4) keadaan perekonomian tidak akan selalu baik. Manajemen waktu adalah suatu cara dalam menggunakan dan mengelola waktu sehingga seluruh perencanaan dan pelaksanaan kegiatan selama satu hari dapat berlangsung secara efektif dan efisien (Guhardja et al. 1992). Manajemen waktu adalah kontrol terhadap kesadaran dari penggunaan waktu untuk memenuhi kebutuhan dan mencapai tujuan. Manajemen waktu dan pekerjaan adalah suatu perencanaan dan pelaksanaan dalam menggunakan sumberdaya waktu untuk mengejakan berbagai pekerjaan agar mencapai keinginan atau tujuan keluarga. Perilaku seseorang dalam mengalokasikan dan menggunakan waktu mencerminkan tingkat kemajuan dan tingkat hidup seseorang atau masyarakat (Puspitawati, 2006).

\section{Metode Penelitian}

\section{Desain, Lokasi dan Waktu Penelitian}

Penelitian ini merupakan bagian dari disertasi yang berjudul "Kajian Manajemen Sumberdaya Keluarga dan Ketahanan Keluarga Peserta Pemberdayaan Masyarakat di Pedesaan". Desain penelitian adalah crossectional study dan teknik pengumpulan data dilakukan dengan metode survei. Lokasi penelitian adalah di Kecamatan Dramaga, Leuwisadeng, dan Pamijahan, Kabupaten Bogor. Pemilihan lokasi dilakukan secara purposive, dengan pertimbangan (1) Kabupaten Bogor masih menempati jumlah penduduk miskin tertinggi di Jawa Barat selama priode 20062009; (2) Tingkat kemiskinan di Kabupaten Bogor yang terus meningkat selama periode 2007-2009; dan (3) Kabupaten Bogor terdapat beberapa program pemberdayaan yang dilaksanakan oleh berbagai pihak yaitu pemerintah, swasta dan perguruan tinggi. Waktu penelitian dilaksanakan selama delapan bulan, terhitung mulai bulan Februari-Oktober 2010.

\section{Populasi dan Sampel Penelitian}

Populasi penelitian adalah seluruh keluarga peserta program pemberdayaan masyarakat di tiga kecamatan. Sampel penelitian adalah keluarga peserta program pemberdayaan masyarakat dan telah menjadi peserta program minimal satu tahun. Teknik pengambilan sampel adalah stratified propotional random sampling. Jumlah sampel yang diambil berdasarkan rumus Slovin yaitu 300 responden, dengan rincian 77 dari Kecamatan Dramaga, 119 dari Kecamatan Leuwisadeng, dan 104 dari Kecamatan Pamijahan. 
Tabel 1. Peubah, indikator dan skala data yang digunakan dalam penelitian

\begin{tabular}{lll}
\hline \multicolumn{1}{c}{ Peubah } & \multicolumn{1}{c}{ Indikator } & \multicolumn{1}{c}{ Skala Data } \\
\hline Karakteristik Keluarga & Pendidikan suami dan isteri (th) & Rasio \\
& Pekerjaan suami dan isteri & Nominal \\
& Umur suami (th) & Rasio \\
& Jumlah Anggota keluarga (orang) & Rasio \\
& Pendapatan (Rp) & Rasio \\
Partisipasi dalam penyuluhan & Keterlibatan mengikuti kegiatan penyuluhan & Ordinal \\
& Keberadaan pendampingan & Nominal \\
Komunikasi & Pola komunikasi & Ordinal \\
Manajemen sumberdaya & Manajemen keuangan & Ordinal \\
keluarga & Manajemen waktu & Ordinal \\
& Strategi koping & Ordinal \\
\hline
\end{tabular}

\section{Jenis dan Sumber Data}

Jenis data yang dikumpulkan terdiri atas data primer dan sekunder. Data primer dikumpulkan melalui wawancara menggunakan kuesioner, terdiri dari: (1) karakteristik keluarga, (2) partisipasi dalam penyuluhan, (3) komunikasi keluarga, dan (4) manajemen sumberdaya keluarga. Indikator dan skala data dari masing-masing peubah dapat dilihat pada Tabel 1. Data sekunder diperoleh dari kantor desa setempat, Badan Pemberdayaan Masyarakat Perdesaan (BPMD) Kabupaten Bogor dan sekretariat program pemberdayaan di masing-masing kecamatan. Data sekunder yang diambil dalam penelitian ini adalah monografi kecamatan, tingkat kemiskinan setiap kecamatan dan jumlah penerima manfaat program pemberdayaan.

\section{Pengolahan dan Analisis Data}

Pengolahan data dilakukan dengan menggunakan Microsoft excel, dan SPSS versi 13 for Windows. Data dianalisis secara deskriptif untuk menggambarkan karakteristik keluarga, komunikasi, partisipasi dalam kegiatan penyuluhan, dan manajemen sumberdaya keluarga. Analisis regresi linier berganda digunakan untuk melihat faktor-faktor yang berpengaruh terhadap praktek manajemen sumberdaya keluarga.

\section{Hasil dan Pembahasan}

\section{Karakteristik Responden}

Rata-rata umur suami 43,8 tahun, dan isteri 37,49 tahun (Tabel 2). Sebagian besar pasangan suami isteri termasuk usia produktif. Hasil analisis tidak ada perbedaan umur isteri dan suami di tiga kecamatan $(\alpha<0.05)$. Ratarata lama pendidikan suami 6,3 tahun dan isteri 5,8 tahun, menunjukkan bahwa tingkat pendidikan responden termasuk rendah. Hasil analisis menunjukkan perbedaan nyata antara pendidikan suami dan isteri di Kecamatan Leuwisadeng dengan Dramaga dan Pamijahan $(\alpha<0,05)$. Lebih dari setengah $(55,7 \%)$ responden memiliki jumlah anggota keluarga antara 5-7 orang dengan rata-rata 5 orang. Menurut BKKBN (1996) jumlah tersebut termasuk kategori sedang. Lebih dari setengah responden $(58,7 \%)$ memiliki pendapatan perkapita di atas Rp 178 835. Berdasarkan garis kemiskinan Kabupaten Bogor 2009, keluarga tersebut relatif tidak miskin. Hasil uji statistik menunjukkan adanya perbedaan nyata antara ratarata jumlah anggota keluarga, dan pendapatan perkapita, antara Kecamatan Leuwisadeng dengan Dramaga dan Pamijahan $(\alpha<0,05)$. Lebih dari setengan responden $(53,7 \%)$ memiliki pasangan suami isteri bekerja. Persentase tertinggi pekerjaan suami adalah buruh, sedangkan isteri berdagang. Jika dilihat berdasarkan kecamatan, Kecamatan Leuwisadeng memiliki jumlah keluarga miskin paling banyak, dan jumlah pasangan suami isteri bekerja paling rendah dibandingkan dua kecamatan lainnya. 
Tabel 2. Sebaran responden berdasarkan peubah karakteristik keluarga

\begin{tabular}{|c|c|c|c|c|c|}
\hline \multirow{2}{*}{ No } & \multirow{2}{*}{ Peubah } & \multicolumn{3}{|c|}{ Kecamatan } & \multirow{2}{*}{ Total } \\
\hline & & Dramaga & Leuwisadeng & Pamijahan & \\
\hline 1 & Umur Suami (th) & $43,8 \pm 40,5$ & $45,0 \pm 10,7$ & $42,2 \pm 8,6$ & $43,8 \pm 10,0$ \\
\hline 2 & Umur Isteri (th) & $38,1 \pm 10,1$ & $38,0 \pm 9,4$ & $36,5 \pm 83,6$ & $37,5 \pm 9,6$ \\
\hline 3 & Pendidikan suami (th) & $6,9 \pm 3,7$ & $5,3 \pm 3,0$ & $7,1 \pm 3.1$ & $6,3 \pm 3,3$ \\
\hline 4 & Pendidikan isteri (th) & $6,0 \pm 3,9$ & $5,1 \pm 2,7$ & $6,5 \pm 2,6$ & $5,8 \pm 3,1$ \\
\hline \multirow[t]{5}{*}{5} & $\begin{array}{l}\text { Jumlah Anggota keluarga } \\
\text { (orang) }\end{array}$ & & & & \\
\hline & $1-4($ kecil $)$ & $45,5 \%$ & $19,3 \%$ & $41,3 \%$ & $33,7 \%$ \\
\hline & $5-7$ (sedang) & $45,4 \%$ & $65,5 \%$ & $51,9 \%$ & $55,7 \%$ \\
\hline & $>7$ (besar) & $9,1 \%$ & $15,1 \%$ & $6,7 \%$ & $10,7 \%$ \\
\hline & $\begin{array}{l}\text { Rata-rata } \pm \text { std } \\
\text { Pendapatan perkapita }\end{array}$ & $4,9 \pm 1,65$ & $5,8 \pm 1,54$ & $5,0 \pm 1,72$ & $5,3 \pm 1,68$ \\
\hline \multirow{3}{*}{6} & < Rp 178835 (miskin) & $33,8 \%$ & $68,1 \%$ & $16,3 \%$ & $41,3 \%$ \\
\hline & > Rp 178835 (tidak miskin) & $66,2 \%$ & $31,9 \%$ & $83,7 \%$ & $58,7 \%$ \\
\hline & Rata-rata \pm std & $524955,2 \pm 551592,2$ & $209316,0 \pm 253904,6$ & $532465,8 \pm 390415,4$ & $402355,3 \pm 424117$ \\
\hline \multirow[t]{3}{*}{7} & Status bekerja suami isteri & & & & \\
\hline & Suami atau isteri saja bekerja & $40,3 \%$ & $58,8 \%$ & $36,5 \%$ & $46,3 \%$ \\
\hline & Suami isteri bekerja & $59,7 \%$ & $41,2 \%$ & $63,5 \%$ & $53,7 \%$ \\
\hline
\end{tabular}

\section{Partisipasi dalam Penyuluhan}

Tingkat partisipasi responden dalam penyuluhan adalah masih rendah. Hal ini ditunjukkan oleh sebagian besar $(89,3 \%)$ responden tidak pernah berpartisipasi dalam kegiatan penyuluhan (Tabel 3). Alasan tidak mengikuti penyuluhan karena tidak adanya kegiatan penyuluhan yang diselenggarakan oleh program pemberdayaan dan sebagian kecil $(1,1 \%)$ responden menyatakan alasan tidak ada waktu karena berjualan dan punya anak kecil. Berdasarkan hasil wawancara di lapangan, kegiatan yang biasanya diikuti oleh responden adalah pertemuan pada saat pencarian dana atau pada saat verifikasi calon penerima dana pinjaman. Sebagian besar $(82 \%)$ responden menyatakan tidak pernah mendapatkan pendampingan dari program pemberdayaan. Jika dilihat berdasarkan kecamatan maka responden di Kecamatan Dramaga paling sering mengikuti penyuluhan, hal ini terkait dengan program PUAP yang melibat- kan GAPOKTAN dan penyuluh pertanian. Menurut Slamet (2003), syarat yang diperlukan agar masyarakat dapat berpartisipasi adalah adanya kesempatan dalam pembangunan, kemampuan untuk memanfaatkan kesempatan, dan adanya kemauan untuk berpartisipasi. Hasil penelitian Setyarini (1990), intensitas penyuluhan berpengaruh nyata terhadap tingkat partisipasi masyarakat.

\section{Manajemen Sumberdaya Keluarga}

Persentase tertinggi $(46,3 \%)$ responden melaksanakan manajemen keuangan dengan baik (Tabel 4). Manajemen keuangan yang baik ditandai oleh seringnya responden menghitung perkiraan biaya hidup sehari-hari, membandingkan penerimaan dan pengeluaran, menyisihkan uang untuk membayar hutang, membuat prioritas pengeluaran, menyelesaikan masalah keuangan secara bersama dengan suami dan anak, serta mengajarkan manajemen keuangan pada anak. Hasil analisis

Tabel 3. Sebaran responden berdasarkan peubah partisipasi dalam penyuluhan

\begin{tabular}{llcccc}
\hline \multirow{2}{*}{ No } & \multicolumn{1}{c}{ Peubah } & \multicolumn{3}{c}{ Kecamatan } & \multirow{2}{*}{ Total } \\
\cline { 3 - 5 } 1 & Dramaga & Leuwisadeng & Pamijahan & \\
\cline { 3 - 4 } 1 & Partisipasi dalam penyuluhan & & $\%$ & $\%$ & \\
& Sering & 15,6 & 7,6 & 2,9 & 8,0 \\
& Kadang-kadang & 3,9 & 0,8 & 0,0 & 1,3 \\
& Jarang sekali & 1,3 & 0,8 & 1,9 & 1,3 \\
& Tidak pernah & 79,2 & 90,8 & 95,1 & 89,3 \\
2. & Keberadaan pendampingan & 31,7 & 15,1 & 11,5 & 18,0 \\
\hline
\end{tabular}


Tabel 4 Sebaran responden berdasarkan kategori manajemen sumberdaya keluarga

\begin{tabular}{|c|c|c|c|c|c|c|c|c|}
\hline \multirow{2}{*}{ Kategori } & \multicolumn{2}{|c|}{ Dramaga } & \multicolumn{2}{|c|}{ Leuwisadeng } & \multicolumn{2}{|c|}{ Pamijahan } & \multicolumn{2}{|c|}{ Total } \\
\hline & $\mathrm{n}$ & $\%$ & $\mathrm{n}$ & $\%$ & $\mathrm{n}$ & $\%$ & $\mathrm{n}$ & $\%$ \\
\hline \multicolumn{9}{|l|}{ 1. Manajemen Keuangan } \\
\hline a. Kurang $(1,2-.2,2)$ & 17 & 22,1 & 58 & 48,7 & 23 & 22,1 & 98 & 32,7 \\
\hline b. Cukup $(2,3-2,6)$ & 12 & 15,6 & 25 & 21,0 & 26 & 25,0 & 63 & 21,0 \\
\hline c. Baik $(2,6-3,7)$ & 48 & 62,3 & 36 & 30,3 & 55 & 52,9 & 139 & 46,3 \\
\hline Total & 77 & 100.0 & 119 & 100,0 & 104 & 100,0 & 300 & 100,0 \\
\hline Skor \pm Std & \multicolumn{2}{|c|}{$2,6 \pm 0.4$} & \multicolumn{2}{|c|}{$2,2 \pm 0.5$} & \multicolumn{2}{|c|}{$2,5 \pm 0,5$} & \multicolumn{2}{|c|}{$2,4 \pm 0,5$} \\
\hline \multicolumn{9}{|l|}{ 2. Manajemen waktu } \\
\hline a. Kurang $(1,0-.2,1)$ & 15 & 19,5 & 48 & 40,3 & 38 & 36,5 & 101 & 33,7 \\
\hline b. Cukup $(2,2-2,6)$ & 34 & 44,2 & 36 & 30,3 & 31 & 29,8 & 101 & 33,7 \\
\hline c. Baik $(2,6-3,7)$ & 28 & 36,4 & 35 & 29,4 & 35 & 33,7 & 98 & 32,7 \\
\hline Total & 77 & 100,0 & 119 & 100,0 & 104 & 100,0 & 300 & 100,0 \\
\hline Skor \pm Std & \multicolumn{2}{|c|}{$2,5 \pm 0,4$} & \multicolumn{2}{|c|}{$2,4 \pm 0,5$} & \multicolumn{2}{|c|}{$2,4 \pm 0,5$} & \multicolumn{2}{|c|}{$2,4 \pm 0,5$} \\
\hline \multicolumn{9}{|l|}{ 3. Strategi koping } \\
\hline a. Kurang (skor 2,4-3,1) & 12 & 15,6 & 18 & 15,1 & 19 & 18,3 & 49 & 16,3 \\
\hline b. Sedang (skor 3,2-3,7) & 24 & 31,2 & 47 & 39,5 & 42 & 40,4 & 113 & 37,7 \\
\hline c. Tinggi (skor $3,7-5,0$ ) & 41 & 53,2 & 54 & 45,4 & 43 & 41,3 & 138 & 46,0 \\
\hline Total & 77 & 100,0 & 119 & 100,0 & 104 & 100,0 & 300 & 100,0 \\
\hline Skor \pm Std & \multicolumn{2}{|c|}{$3,7 \pm 0,5$} & \multicolumn{2}{|c|}{$3,6 \pm 0,5$} & \multicolumn{2}{|c|}{$3,5 \pm 0,5$} & \multicolumn{2}{|c|}{$3,6 \pm 0,5$} \\
\hline \multicolumn{9}{|l|}{ 4. Manajemen sumberdaya keluarga } \\
\hline a. Kurang (skor 5-7,9) & 19 & 24,7 & 54 & 45,4 & 33 & 31,7 & 106 & 35,3 \\
\hline b. Sedang (skor 8,0-8,8) & 26 & 33,8 & 37 & 31,1 & 34 & 32,7 & 97 & 32,3 \\
\hline c. Tinggi (skor 8,9-11,0) & 32 & 41,6 & 28 & 23,5 & 37 & 35,6 & 97 & 32,3 \\
\hline Total & 77 & 100,0 & \multirow{2}{*}{\multicolumn{2}{|c|}{$119 \begin{array}{c}100,0 \\
82+10\end{array}$}} & \multirow{2}{*}{\multicolumn{2}{|c|}{$\begin{array}{c}104 \quad 100,0 \\
8,4+0.9\end{array}$}} & \multirow{2}{*}{\multicolumn{2}{|c|}{$\begin{array}{c}300 \quad 100,0 \\
8.4+0.9\end{array}$}} \\
\hline Skor \pm Std & \multicolumn{2}{|c|}{$8,7 \pm 0,9$} & & & & & & \\
\hline
\end{tabular}

statistik, terdapat perbedaan nyata antara manajemen keuangan di Kecamatan Leuwisadeng dengan Kecamatan Dramaga dan Pamijahan $(\alpha<0,05)$.

Kualitas manajemen waktu yang dilakukan oleh responden menyebar pada cukup dan kurang, dengan jumlah masing-masing 33,7 persen. Manajemen waktu kurang baik ditandai oleh responden tidak pernah merencanakan kegiatan dengan tertib, baik untuk diri sendiri maupun untuk anggota. Beberapa hal yang sering dilakukan responden adalah meluangkan waktu bersama keluarga dan nonton televisi bersama. Hasil analisis, tidak menunjukkan adanya perbedaan nyata di antara ketiga kecamatan $(\alpha<0,05)$.

Strategi koping terdiri dari dua bagian yaitu strategi penghematan dan peningkatan pendapatan (Puspitawati 1992). Persentase tertinggi responden $(46,0 \%)$ melakukan strategi koping tergolong tinggi. Pada penelitian ini, strategi koping yang tinggi ditandai oleh semakin banyaknya keluarga melakukan penghematan, terutama pada aspek pangan dan kesehatan. Upaya responden dalam pe- ningkatan pendapatan, lebih banyak dilakukan responden di Kecamatan Dramaga. Hasil analisis menunjukkan adanya perbedaan nyata strategi koping keluarga di Kecamatan Dramaga dengan Pamijahan $(\alpha<0,05)$. Hasil penelitian Shaffer et al. (1996) menunjukkan, kemudahan akses dan ketersediaan fasilitas umum seperti transportasi umum, fasilitas kesehatan, dan pasar akan memudahkan keluarga dalam memilih strategi koping yang akan dilakukan. Penelitian Puspitawati (1992) menunjukkan, faktor-faktor yang mempengaruhi strategi koping keluarga adalah karakteristik sosial ekonomi, karakteristik demografi, dan wilayah tempat tinggal.

Secara keseluruhan manajemen sumberdaya keluarga dengan memperhatikan manajemen keuangan, waktu dan strategi koping, persentase tertinggi $(35,3 \%)$ responden termasuk kurang baik dalam melakukan manajemen sumberdaya keluarga. Terdapat perbedaan nyata manajemen sumberdaya keluarga di Kecamatan Leuwisadeng dengan Kecamatan Dramaga dan Pamijahan $(\alpha<0,05)$. 
Tabel 5. Sebaran responden berdasarkan kategori komunikasi keluarga

\begin{tabular}{lccccccccc}
\hline \multirow{2}{*}{ Kategori } & \multicolumn{2}{c}{ Dramaga } & \multicolumn{2}{c}{ Leuwisadeng } & \multicolumn{2}{c}{ Pamijahan } & \multicolumn{2}{c}{ Total } \\
\cline { 2 - 10 } & $\mathrm{n}$ & $\%$ & $\mathrm{n}$ & $\%$ & $\mathrm{n}$ & $\%$ & $\mathrm{n}$ & $\%$ \\
\hline Kurang (skor 1,1-2,1) & 32 & 41,5 & 51 & 42,8 & 23 & 22.1 & 106 & 35.3 \\
Cukup (skor 2,2-2,6) & 17 & 22,1 & 27 & 22,7 & 21 & 20.2 & 65 & 21.7 \\
Baik (skor 2,7-3,7) & 28 & 36,4 & 41 & 34,5 & 60 & 57.7 & 129 & 43.0 \\
\hline \multicolumn{2}{c}{ Total } & 77 & 100 & 119 & 100 & 104 & 100 & 300 & 100.0 \\
\hline \multicolumn{2}{c}{ Rata-rata skor \pm Std } & \multicolumn{2}{c}{$2,3 \pm 0,5$} & $2,2 \pm 0,5$ & & $2,6 \pm 0,5$ & & $2,4 \pm 0,5$ \\
\hline
\end{tabular}

\section{Komunikasi Keluarga}

Persentase tertinggi responden tergolong baik dalam komunikasi antara anggota keluarganya. Komunikasi yang baik lebih banyak ditemukan di Kecamatan Pamijahan (57,7\%), sedangkan di Kecamatan Leuwisadeng dan Dramaga, persentase tertinggi (lebih dari 40\%) termasuk kategori kurang (Tabel 5). Hasil uji statistik menunjukkan adanya perbedaan yang nyata antara komunikasi keluarga di Kecamatan Dramaga dan Leuwisadeng dengan Kecamatan Pamijahan $(\alpha<0,05)$. Pada penelitian ini komunikasi yang baik ditandai oleh seringnya komunikasi pada saat nonton televisi, peyelesaikan masalah bersama, penyampaian ide baru, dan pada saat makan malam. Menurut Guhardja et al (1992), salah satu faktor yang mempengaruhi efektivitas dan efisiensi komunikasi keluarga adalah tingkat pendidikan orang tua.

\section{Pengaruh Karakteristik, Komunikasi dan Partisipasi Keluarga dalam Penyuluhan Terhadap Manajemen Sumberdaya Keluarga}

Hasil analisis regresi linier berganda menunjukkan bahwa karakteristik keluarga yaitu pendapatan perkapita, kualitas komunikasi keluarga, status bekerja suami isteri dan partisipasi penyuluhan berpengaruh nyata terhadap praktik manajemen sumberdaya keluarga (Tabel 6). Nilai adjusted $R$ square adalah 0,253 , hal ini berarti 25,3 persen dari peubah-peubah tersebut berpengaruh terhadap kualitas manajemen sumberdaya keluarga, dan sisanya dipengaruhi oleh peubah lain yang tidak diteliti.

Pendapatan perkapita berpengaruh negatif dan nyata terhadap manajeman sumberdaya keluarga. Hal ini berarti setiap penurunan pendapatan satu poin, akan meningkatkan kualitas manajemen sumberdaya keluarga sebanyak 0,177 poin. Menurut Gross et al. (1980), pada kondisi sumberdaya yang terbatas maka proses manajemen sumberdaya akan semakin meningkat. Conger dan Elder (1994) menyatakan, keluarga yang memiliki pendapatan rendah cenderung melakukan manajemen sumberdaya yang dimiliki menjadi lebih baik untuk mengurangi masalah ekonomi yang dihadapi. Gunawan dan Sugiyanto (1999) menyatakan, keluarga miskin seringkali mengerahkan anggota keluarganya untuk mencari nafkah, sehingga perencanaan dan pelaksanaan penggunaan sumberdaya waktu menjadi lebih produktif karena digunakan untuk mengerjakan berbagai pekerjaan sebagai upaya untuk memenuhi kebutuhan hidup.

Komunikasi berpengaruh positif sangat nyata terhadap manajemen sumberdaya keluarga. Hasil menunjukkan setiap kenaikan satu poin kualitas komunikasi keluarga maka akan menaikkan 0.604 poin kualitas manajemen sumberdaya keluarga. Guhardja et al. (1992) menyatakan bahwa komunikasi dalam keluarga merupakan hal yang penting karena dengan komunikasi, interaksi dalam keluarga akan terjadi lebih baik sehingga proses manajemen sumberdaya keluarga menjadi lebih baik.

Status bekerja pasangan suami isteri berpengaruh positif sangat nyata terhadap manajemen sumberdaya keluarga. Hal ini berarti pasangan suami isteri yang bekerja menghasilkan manajemen sumberdaya keluarga yang lebih baik 0,433 poin dibandingkan dengan salah satu pasangan yang bekerja. Christine et al. (2010) menyatakan, suami isteri yang sama-sama bekerja saling memahami kondisi masing-masing sehingga konflik pekerjaan dan keluarga dapat dikelola dengan baik yang akhirnya dapat memberikan kepuasan dalam hidup berkeluarga. 
Tabel 6. Hasil analisis regresi linier berganda pengaruh karakteristik, komunikasi, dan partisipasi keluarga dalam penyuluhan terhadap manajemen sumberdaya keluarga

\begin{tabular}{|c|c|c|c|c|c|}
\hline \multirow[t]{2}{*}{ No } & \multirow[t]{2}{*}{ Peubah bebas } & $\begin{array}{l}\text { Unstandardized } \\
\text { Coefficients }\end{array}$ & $\begin{array}{l}\text { Standardized } \\
\text { Coefficients }\end{array}$ & \multirow[t]{2}{*}{$\mathrm{t}$} & \multirow[t]{2}{*}{ Sig } \\
\hline & & $\mathrm{B}$ & Beta & & \\
\hline & Constant & 6.704 & & & \\
\hline 1. & Pendapatan/kapita & $-0,177$ & $-0,159$ & $-2,676$ & 0,008 \\
\hline 2. & Jumlah anggota keluarga & 0,059 & 0.037 & 0,692 & 0,489 \\
\hline 3. & Pendidikan isteri & 0,005 & 0.015 & 0,245 & 0,807 \\
\hline 4. & Pendidikan suami & 0,025 & 0.083 & 1,350 & 0,178 \\
\hline 5. & Kualitas Komunikasi keluarga & 0,604 & 0.321 & 5,775 & 0,000 \\
\hline 6. & $\begin{array}{l}\text { Status bekerja suami isteri }(1=\text { pasangan suami } \\
\text { isteri bekerja;0=salah satu yang bekerja) }\end{array}$ & 0,433 & 0.219 & 3,931 & 0,000 \\
\hline 7. & $\begin{array}{l}\text { Partisipasi penyuluhan }(1=\text { ikut } \\
\text { penyuluhan; } 0=\text { tidak ikut })\end{array}$ & 0,901 & 0.266 & 5,268 & 0,000 \\
\hline
\end{tabular}

Adjusted R Square $=0,252$

Menurut Scanzoni (Puspitawati 2010), suami isteri yang bekerja, pada umumnya mereka tidak hanya berbagi dalam hal pendapatan, namun juga berbagai dalam urusan rumah tangga dan mengurus anak. Berdasarkan hal tersebut maka adanya sikap berbagi dalam urusan rumah tangga dan kemampuan mengelola konflik dalam keluarga menyebabkan manajemen sumberdaya keluarga menjadi lebih baik.

Partisipasi dalam menyuluhan berpengaruh positif sangat nyata terhadap manajemen sumberdaya keluarga. Hal ini memberi makna bahwa responden yang berpatisipasi dalam penyuluhan berpengaruh terhadap kualitas manajemen sumberdaya keluarga yang lebih baik dibandingkan dengan yang tidak pernah aktif. Hasil studi ethnografi Hashemi et al. (1996) terhadap kajian dampak pemberdayaan perempuan pada Grameen Bank terhadap dimensi nonekonomi menunjukkan bahwa adanya peningkatan partisipasi perempuan dalam mengikuti pertemuan rutin mingguan, dan berbagai pelatihan. Temuan lain dari studi tersebut adalah anggota keluarga menjadi perhatian terhadap alokasi waktu terutama pada saat isteri aktif mengikuti pertemuan rutin dan pelatihan, serta pengembalian kredit bergulir menjadi lebih lancar karena manajemen keuangan menjadi lebih baik. Kajian etnografi Hashemi et al. (1996) mendukung terhadap temuan penelitian ini yaitu partisipasi perempuan dalam kegiatan penyuluhan memberikan pengaruh terhadap proses manajemen sumberdaya keluarga.

\section{Kesimpulan}

Sebagian besar usia suami dan isteri termasuk usia produktif dan jumlah anggota keluarga termasuk kategori sedang. Lebih dari setengah keluarga memiliki pendapatan perkapita di atas garis kemiskinan, dan 41.3 tergolong miskin. Tingkat pendidikan responden masih rendah dan lebih dari setengah pasangan suami isteri tergolong produktif dalam mencari nafkah.

Persentase tertinggi responden telah melakukan manajemen keuangan dengan baik, manajemen waktu menyebar pada kategori cukup dan kurang, dan strategi koping yang dilakukan responden tergolong tinggi. Secara keseluruhan praktek manajemen sumberdaya keluarga termasuk kurang baik.

Faktor yang berpengaruh positif dan nyata terhadap praktek manajemen sumberdaya keluarga adalah kualitas komunikasi keluarga, status bekerja suami isteri dan partisipasi dalam kegiatan penyuluhan. Faktor yang berpengaruh negatif dan nyata terhadap praktek manajemen sumberdaya keluarga adalah pendapatan perkapita.

Diperlukan penyuluhan mengenai: (1) manajemen sumberdaya keluarga untuk meningkatkan pengetahuan dan keterampilan sehingga kemampuan melakukan manajemen sumberdaya keluarga menjadi lebih baik; (2) komunikasi keluarga, untuk meningkatkan pengetahuan dan keterampilan melakukan komunikasi sehingga dapat mendukung peningkatan kualitas manajemen sumberdaya keluarga 
Peningkatan kegiatan penyuluhan dan pelatihan terhadap peserta program pemberdayaan masyarakat yang disertai pengembangan dan peningkatan kompetensi penyuluh.

\section{Daftar Pustaka}

Asngari PS. 2001. Peranan Agen Pembaruan/Penyuluh Dalam Usaha Memberdayakan (Empowerment) Sumberdaya Manusia Pengelola Agribisnis. Orasi Guru Besar Tetap Sosial Ekonomi, Fakultas Peternakan, IPB. Bogor.

Celik SB. 2007. Family Function Levels of Turkish Fathers with Children Aged Between 0-6. Social Behavior and Personality. Palmerston North. Vol. 35, No.4: pg 429.

Chamber R. 1995. Pembangunan Desa : Mulai dari Belakang. Jakarta. LP3ES.

Conger RD, Elder GH. 1994. Families in troubled times. The Iowa Youth and Family Project. In RD. Conger \& GH Elder $\mathrm{Jr}$ (Eds). Families in troubled times: Adapting to change in rural America. New York: hlm 3-19.

Christine WS, Oktorina M, Mula I. 2010. "Pengaruh Konflik Pekerjaan dan Konflik Keluarga Terhadap Kinerja dengan Konflik Pekerjaan Keluarga Sebagai Intervening Variabel (Studi pada Dual Career Couple di Jabodetabek)." Jurnal Manajemen dan Kewirausahaan, Vol. 12, No. 2, September $2010: 121-132$ (Diakses 29 Agustus 2011)

Deacon RE, Firebaugh FM. 1988. Family Resources Management : Principles and Applications ( $\left.2^{\text {nd }} e d\right)$. Massachusettes. Allyn and Bacon.

Fuaida LD. 2007. Manajemen Keuangan Keluarga Miskin: "Studi Kasus Mitra Program Masyarakat Mandiri, Dompet Dhuafa Republika." Jakarta: Program Pascasarjana Universitas Indonesia.

Gross IH, Crandall EW, Knoll MM. 1980. Management for Modern Families. New Jersey. Prentice-Hall, Inc.

Guhardja S, Puspitawati H, Hartoyo, Hastuti D. 1992. Manajemen Sumberdaya Keluarga. Diktat Kuliah Manajemen Sumberdaya Keluarga. Bogor: Departemen
Gizi Masyarakat dan Sumberdaya Keluarga, Fakultas Pertanian, IPB.

Gunawan dan Sugiyanto. 1999. "Kondisi keluarga fakir miskin." Jurnal Ekonomi Rakyat 3:15-22

Hashemi S.M, S.D. Schuler, dan A. N. Riley. 1996. "Rural Credit Programs and Women's Empowerment in Bangladesh." Worl Developlment, Vol 24 (4), pp 635653.

Iskandar A. 2007. Analisis Praktek Manajemen Sumberdaya Keluarga dan Dampaknya Terhadap Kesejahteraan Keluarga di Kabupaten dan Kota Bogor. Bogor: Sekolah Pascasarjana, Institut Pertanian Bogor.

Lubis Z. 2006. Penanggulangan Kemiskinan. www.waspada.co.id (Diakses 20 Juni 2009).

Puspitawati H. 1992. Time Management Strategies Used In Households in Which Income is Generated at Home. Iowa State University. Ames Iowa.

Puspitawati H. 2006. Manajemen Keuangan Keluarga Sebagai Bagian dari Manajemen Sumberdaya Keluarga Berwawasan Gender. Modul Pelatihan. Kader Posyandu Dan PKK dan Aparat Kelurahan Tentang Pendidikan Keluarga Berwawasan Gender (PKBG). Desa Situgede, Kecamatan Bogor Barat, Jawa Barat. 22-24 Desember 2006

Puspitawati H. 2010. Teori Gender dan Aplikasinya dalam Kehidupan Keluarga. Bogor. Departemen Ilmu Keluarga dan Konsumen, Fakultas Ekologi Manusia, Institut Pertanian Bogor.

Santoso U. 2007. Pentingnya Pengelolaan Keuangan Keluarga. http://uripsantoso. wordpress.com.

Satria A. 2009. Ekologi Pollitik Nelayan, Yogyakarta: PT LKIS Printing Cemerlang

Setyarini D. 1990. Pengaruh Intensitas Penyuluhan terhadap Partisipasi Masyarakat dalam Program Penghijauan Kota. eprints.lib.ui.ac.id (Diakses 22 Sept 2011).

Shaffer R, Ziebarth A, Farnham J. Wraith S, dan Tigges L. 1996. "Lingking Coтmunity Resource to Family Survival Strategies. Papper originally presented at 
1996." Annual meeting of The Community Development Society, Melbourne, VIC, Australia.

Slamet M. 2003. "Meningkatkan Partisipasi Masyarakat dalam Pembangunan Masyarakat." Dalam Membentuk Pola Perilaku Manusia Pembagunan. Bogor, IPB Press.

Sumodingrat G. 1999. Pemberdayaan Masyarakat dan JPS. Jakarta. PT Sun.
Suparto HP. 2007. Manajemen Keluarga: Upaya Meningkatkan Peran Keluarga dalam Menciptakan Keluarga dan Lingkungan yang Bersih dan Sehat. www. jatim.go.id (Diakses 10 Juni 2009).

Winter M, Puspitawati H. 1993. Time Management Strategies Used by Households with Home-Based Work. Journal of Family and Economic Issues, 14 (1). 